\title{
Pending issues from digital inclusion in Ecuador: challenges for public policies, programs and projects developed and ICT-mediated teacher training
}

\author{
Diego Apolo \\ diego.apolo@unae.edu.ec \\ Universidad Nacional de Educación - UNAE - Ecuador \\ Malena Melo \\ malena.melo@unae.edu.ec \\ Universidad Nacional de Educación - UNAE - Ecuador \\ Johe Solano \\ jssolano@unae.edu.ec \\ Universidad Nacional de Educación - UNAE - Ecuador \\ Felipe Aliaga \\ felipe.aliaga@usantotomas.edu.co \\ Universidad Santo Tomás - Colombia
}

\begin{abstract}
The policies of digital inclusion in Ecuador had a rebound since 2007, placing technology as a priority axis for government management. Despite this, there are still pending issues to be developed. This study is based on a qualitative approach that, through documentary research, bibliographic analysis and critical review of literature, can generate contributions that allow the identification of challenges and possible gaps to be faced by government entities in Ecuador when proposing actions that link education and technology. As main findings, it can be mentioned that the impacts and results from the application of the National Development Plans must transcend the figures, which allow to deepen the analysis in relation to this topic, together with initiatives and proposals that regarding digital inclusion cannot be developed in isolation and need to have comprehensive long-term management. Finally, it is essential to understand that it is not necessary to create only platforms, it is relevant to work from integral pedagogical designs that start by understanding teachers from their experiences, accompaniment and motivation for the design of a contextualized training structure on digital mediation issues.
\end{abstract}

\section{Keywords}

Public policy; digital inclusion; teacher training; challenges; Ecuador. 


\section{Introduction}

The increase in connection speed or the accelerated evolution of devices and tools for accessibility to digital platforms, as stated by Adell (1997), are present in the daily life of societies, configuring them, as well as its culture and meanings. In the same way, geographical barriers are disputed in "the out of place or the non-place" frequented by the subject (Augé, 1993), who is in a transit space. The subject's gaze is embodied by social fields and subjective processes and it attributes him its own character loaded with historicity. In the case of technologies and the place of connection, the space is developed through the network, seeking interactivity and pursuing the encounter of users with their environments.

In this way, it can be observed how different initiatives linked from public policy have promoted deterministic visions of technology, in which the provision of connections and devices has been prioritized. Although provision is truly the first step, it requires more than a decade of work in Ecuador to strengthen sociocritical and humanistic processes that address the link between technology and education.

Based on the above, this article presents some keys from the public policy dialogue, the presentation of initiatives developed by the government on technology issues and a review of studies that highlight challenges for teacher training mediated by Information and Communication Technologies (ICT). In this way, the plots and contexts that are generated between technology, subjects and institutions must be analyzed, since the latter exercise their disciplinary power (Balardini, 2002) in education, consolidating themselves under the structural-functionalist approach, which responds to "the expansion of the capitalist world market" (Rigal, 2004, p. 24), linking consumer relations that are currently crossed by the network.

It is at this moment, when it is necessary to understand that this convergence is not linear, as public policies often intend to establish, it is recognized that they are multidimensional and multidirectional processes that transcend time and space, for which it is required to understand that the communicative interactions are ubiquitous, not only because of their dynamism and immediacy, but for the recognition of different plots, contexts and stories that cross them.

For this reason, the objective of this proposal lies in identifying different proposals that allow mentioning some awaiting points from the digital inclusion processes in Ecuador, based on public policy documents. To do this, three key categories have been taken from the proposals of other studies: 1) analysis of public policy, 2) descriptions of programs and projects developed and 3) challenges for teacher training mediated by ICT.

\section{Materials and methods}

This study was developed under a qualitative approach of descriptive-exploratory scope, through documentary and bibliographic research. As stated by Valles (1999), this type of research is based "on documents collected in archives (official or private); documents of all kinds, whose preparation and survival (deposit) has not necessarily been presided over by social research objectives" ( $p$. 109).

The content analysis was performed following the perspective of López (2002) on the documentary and bibliographic materials collected, carefully studying the documents through a controlled hermeneutical interpretation. A critical literature analysis was used from the contributions of Ramos, Apolo and Jadán (2018), in order to identify studies that have addressed technologymediated teacher training from the Scopus, EBSCO and Redalyc databases of published articles during the period between 2015 and 2018. In addition, this compilation was supplemented with the 
contribution of bibliography published in other years, which is of great value from the perspective approached and is usually recommended by experts.

\section{Results}

\section{a. The need for long-term institutional planning: National Development Plans and proposals for digital inclusion in Ecuador}

In Ecuador, as of 2007, public policies are built through National Development Plans, which are born from the National Secretariat for Planning and Development (Senplades, in Spanish) and which, until now, have derived four plans in different periods of government. This marked a momentous turn in terms of policy management and monitoring, as well as joint work between secretariats and ministries. From this, for the digital inclusion field, new policies were created to improve people's access to communication and information. It is important to mention that, so far, there is no concrete evaluation of these plans and their impact.

In objective 2 of the National Development Plan 2007-2010, Planning for the Citizen Revolution, (Senplades, 2007), the improvement of the capabilities and potential of the citizenry is enunciated, and two policies regarding technology and communication are established:

Policy 2.5. Promote scientific research and technological innovation to encourage sustainable development processes.

Policy 2.6. Promote access to information and new information and communication technologies to strengthen the exercise of citizenship. (p.109)

For the first policy, an increase in investment in technological resources was presented as a strategy; for the second, on the other hand, the strategies were aimed at providing Internet service in public educational centers and promoting the creation of Infocenters with access to telecommunications in rural areas, so that the media promote alternative education spaces both in radio and television. It should be noted that, being one of the first initiatives set by the government of former President Rafael Correa, the objectives were not met. Before meeting them, it was necessary to achieve the articulation between State entities and the disbursement of the initial investment budgets.

The second National Development Plan was designed with goals for the 2009-2013 period, under the name For Good Living (Senplades, 2009). In it, in the same way, objective 2 was framed in improving the capacities and potential of the citizens, achieving the policies of the previous plan with a small addition in the first:

Policy 2.6. Promote scientific research and knowledge, the revaluation of ancestral knowledge and know-how, and technological innovation.

Policy 2.7. Promote access to information and new information and communication technologies to incorporate the population into the information society and strengthen the exercise of citizenship. (p. 173)

In this case, Senplades (2009) established new strategies that evolved considerably. Thus, for the development of the first policy, it was aimed at promoting the creation of educational projects at all levels, based on science and technology. Likewise, for the second policy, strategies linked to the educational field were established, such as democratization of access to technological resources and Internet service, as well as the implementation of infrastructure in rural telecentres and at all levels of education. 
In addition, the fundamental aspect that was pointed out was the promotion of new information systems, communication channels, applications, programs and projects, so that the population enjoys better access opportunities, but not necessarily with an emphasis on the development of digital skills. Although this is true, after the learning of the first years, the intervention of different secretariats and ministries allowed for considerable growth in relation to investment, since the provision of connections and devices did not necessarily emphasize on the training of educational actors.

The third National Development Plan established goals for the 2013-2017 period, called the National Plan For Good Living (Senplades, 2013), in which new digital inclusion policies were created in the objectives:

4. Strengthen the capacities and potential of citizens [...].

5. Build spaces for common encounter and strengthen national identity, diverse identities, plurinationality and interculturality [...].

11. Ensure the sovereignty and efficiency of strategic sectors for industrial and technological transformation. (pp. 59-81)

As evidenced, technology plays an important role and is cross-cutting with the different needs of the Ecuadorian population, both for urban and rural areas. In this plan, the main characteristic was that all the objectives set out aimed at a change in the productive matrix in Ecuador. In this way, technology was a key piece to develop policies and programs on formal and non-formal educational issues.

The policies established by Senplades (2013) to optimize these objectives were as follows:

4.3. Promote non-formal and permanent education spaces for the exchange of knowledge and know-how for the learning society [...].

4.6. Promote reciprocal interaction between education, the productive sector, and scientific and technological research, for the transformation of the productive matrix and the satisfaction of needs [...].

5.5 Guarantee the exercise of the right to free, intercultural, inclusive, responsible, diverse and participatory communication for the population [...].

11.3. Democratize the provision of public telecommunications services and information and communication technologies (ICTs), including broadcasting, television and radio spectrum, and deepen their use and universal access. (pp. 196-401)

In the same way, Senplades (2013) proposed new strategies for the execution and fulfillment of these objectives. Among them, the repowering of public educational infrastructures stands out, referring to the implementation of the Millennium Educational Units, which were centers equipped with connectivity and furniture with Internet access. This way, it was concluded that the more state-of-the-art equipment in public educational institutions, the higher the quality of education, emphasizing an approach from technological determinism in the design of public policies for digital inclusion. Meanwhile, for non-formal educational spaces, generating education campaigns through the digital media and democratizing the access to scientific information, through virtual and freely accessible platforms, were proposed as main strategies.

The goal of the policies proposed in this plan also aimed at financing for the creation of digital educational content and its dissemination in public and private media, which would allow the integral development of people, maintaining cultural relevance and, in turn, promoting respect for collective rights, both of people and of nature (Senplades, 2013). In addition, for the technical and network management area and technology coverage, tactics were proposed that encouraged the 
expansion of connectivity in rural areas, in order to achieve a correct dissemination of the different contents and promote citizen participation.

Although there was a development in implementation strategies and tactics, one of the main problems detected was that many of the actions were managed by the Ministry of Telecommunications and the Information Society (Mintel), regarding both financially and management. This responsibility, which fell to a single ministry, set aside certain critical points that, to date, had not been addressed. The emphasis on technological determinisms centered on artifacts displaced the actors in the educational process, leaving large gaps in teacher training for the correct handling and manipulation of the new equipment that was intended to be established. That is why the strategies did not propose programs that promoted the continuous training of citizens in the use and management of both platforms and digital resources or skills.

Finally, the National Development Plan 2017-2021 was designed by the Government of President Lenin Moreno, under the name An Entire Life (Senplades, 2017). In it, the following axes were established: promoting new audiovisual languages as dynamizers of knowledge, to strengthen the relationship of technology in both formal and non-formal spaces, and working on strategies that enhance training for both teachers and students in the management of digital technologies and resources, to give continuity to initiatives established in previous years.

\begin{tabular}{|l|l|}
\hline \multicolumn{1}{|c|}{ Plan } & \multicolumn{1}{|c|}{ Goal } \\
\hline 2010 & 2.7. Triple Internet access. \\
\hline $\begin{array}{l}\text { National Development Plan 2009- } \\
2013\end{array}$ & $\begin{array}{l}2.7 .1 . \text { Achieve 55\% of rural educational } \\
\text { establishments with Internet access, and 100\% } \\
\text { of urban ones until 2013. } \\
\text { 2.7.2. Triple the percentage of households with } \\
\text { Internet access until 2013. }\end{array}$ \\
\hline $\begin{array}{l}\text { National Development Plan 2013- } \\
2017\end{array}$ & $\begin{array}{l}\text { 4.4. Increase Internet access in educational } \\
\text { establishments to 90\%. } \\
\text { 5.4. Increase the number of nationally } \\
\text { produced audiovisual works to 18. } \\
11.7 . \text { Reduce digital illiteracy to 17.9\%. } \\
11.8 . \text { Increase the percentage of people who } \\
\text { use ICT to 50\%. }\end{array}$ \\
\hline $\begin{array}{l}\text { National Development Plan 2017- } \\
2021\end{array}$ & $\begin{array}{l}\text { Increase coverage, quality and access to } \\
\text { educational services, with cultural and territorial } \\
\text { relevance, in rural areas: increase the } \\
\text { percentage of students enrolled in educational } \\
\text { institutions that have at least the following } \\
\text { services: a) electricity; b) Internet for } \\
\text { pedagogical purposes; c) computers for } \\
\text { pedagogical purposes; d) recreational spaces; } \\
\text { e) water; f) hygienic services, from 58\% to } \\
70 \% \text { in rural areas by 2021. }\end{array}$ \\
\hline
\end{tabular}

Table 1. Goals set out in the four National Development Plans (2007-2017)

Source: adapted from Senplades $(2007,2009,2013,2017)$. 
Thus, the goals set in the National Development Plans (Senplades, 2007; 2009; 2013) have not been evaluated, and the information to know what their scope has been from quantitative and qualitative approaches is not available. For this reason, the governments on duty, when setting scopes with respect to their policies, must establish parameters of compliance and satisfaction among the population, even more in the areas of education and technology, since economic and resource investments have extremely high cost. For the last National Plan established in Ecuador (Senplades, 2017), it is important to follow up on the goals set based on quantitative and qualitative studies that allow interpolation of data, in order to analyze the proposals of government entities and that they can respond to training needs in the digital and knowledge age.

\section{b. Good ideas that require more work: programs and projects for digital inclusion in Ecuador}

The various initiatives in programs and projects for digital inclusion in Ecuador in recent years have aimed at achieving similar goals in education, goals that have been renamed in some cases taking some of the earlier proposals or incorporating new.

It is necessary to indicate, as a background, that in this space a chronological analysis of the programs and projects generated for digital inclusion in Ecuador since 2001 is conducted, in order to contextualize and understand the status of the following proposals for digital inclusion that were implemented between the years object of analysis of this article (2007-2017), as well as what has happened in this regard up to the present time specifically in the educational sector.

For this, five initiatives are identified: (a) National Connectivity Agenda 2002, (b) Strategy for the Development of the Information Society, (c) Ecuador Digital 2.0 Strategy, (d) Integral System of Technologies for School Project and Community (SITEC, in Spanish) and (e) Digital Educational Agenda 2017-2021.

In 2001, Ecuador took its first steps in the process of defining and implementing public policies for the construction of information societies with the National Agenda for Connectivity 2002, whose objective projected the following:

Establish policies, strategies, programs and projects to develop the access infrastructure and the services and applications related to the use of ICTs, and guarantee their use, for the benefit of society in their community, business and government activities, and to serve as basis for the definition of local policies that contribute to territorial development which articulates strategies, programs and projects aimed at the development and diffusion of ICTs in areas such as education, health, the environment, commerce, industry, tourism, security and governance in Ecuadorian society. (Jurado, 2005, p. 49)

This agenda was structured in areas that were considered as priorities for intervention. One of them was Teleeducation (Facultad Latinoamericana de Ciencias Sociales Sede Ecuador [Flacso], 2005), in which projects were determined to improve the quality of education with the inclusion of ICT. In this area, three strategies were proposed with their respective projects, oriented towards: (1) the incorporation of ICT in education in a transversal manner, (2) preferential access to ICT in the educational sector to reduce the gap in ICT skills, and (3) the development of digital culture for the appropriate use of ICT in education through teacher training.

In the Action Plan 2005-2010 of the National Connectivity Agenda, some progress was recorded between 2002 and 2005: (a) the implementation of the educational portal www.educarecuador.gob.ec, which made didactic contents for different areas and levels of the country's national education system available to the educational community; (b) the development of online content for urban and rural educational institutions in the province of Pichincha; (c) the development of multimedia educational software for basic general education; (d) the delivery of 
technological equipment to rural educational institutions in the province of Pichincha; and (e) the training of teachers in the public educational system from some provinces of the Sierra region (Pichincha, Chimborazo and Cotopaxi) and Costa (Guayas) (Consejo Nacional de Telecomunicaciones [Conatel], 2005).

After the analysis and evaluation of the National Agenda for Connectivity, the results of which were published in the Libro Blanco para la Sociedad de la Información en Ecuador (Conatel, 2006), it was concluded that the ICT inclusion needs in the country were not met, because some of these proposals were very ambitious and little planned in the determined times for their implementation. This Teleeducation program should have proposed articulated projects to achieve a successful inclusion of ICT in education, and not as isolated efforts that unfortunately did not allow the fulfillment of the objectives set.

In this way, a new proposal was started called the Strategy for the Development of the Information Society (EDSI, by its initials in Spanish), made up of three axes. In particular, its second axis "Socialization, appropriation and enabling environment", which included the Education field, was directed towards improving educational quality through the appropriate use of ICTs in the information society, aimed at the development of digital skills in students and teachers. Unfortunately, due to the administrative changes of Conatel (2006), this new strategy was excluded from planning in the following governments, being relegated to the participation of sectors of civil society, the private sector and the State.

In 2011, Mintel presented the Ecuador Digital 2.0 Strategy, articulated with the National Development Plan 2009-2013 For Good Living, in order to guarantee access to ICTs, contributing to the country's social and economic development through the implementation of multiple projects. This strategy was based on:

Set of Sectoral Policies promoted by Mintel, so that all citizens access and generate information and knowledge, through the effective use of information and communication technologies, actively integrated into the process of social and solidarity development in Ecuador. (Mintel, 2011, p. 24)

The goals achieved until 2015 by the Ecuador Digital 2.0 Strategy, related to the education sector, are presented in Table 2 .

Table 2. Goals achieved by the Ecuador Digital 2.0 Strategy related to the education sector

\begin{tabular}{|l|l|l|}
\hline \multicolumn{1}{|c|}{ Plan } & \multicolumn{1}{|c|}{ Description } & \multicolumn{1}{c|}{ Goal } \\
\hline $\begin{array}{l}\text { National School } \\
\begin{array}{l}\text { Connectivity Plan } \\
\text { (Corporación Andina de } \\
\text { Fomento [CAF], 2013). }\end{array}\end{array}$ & $\begin{array}{l}\text { Publicly supported educational } \\
\text { establishments with } \\
\text { technological equipment and } \\
\text { Internet access. }\end{array}$ & $\begin{array}{l}\text { As of 2015,9,732 } \\
\text { establishments with } \\
\text { connectivity. }\end{array}$ \\
\hline $\begin{array}{l}\text { Infocenters (Mintel, } \\
\text { 2011). }\end{array}$ & $\begin{array}{l}\text { Parishes with implementation } \\
\text { of Infocenters. }\end{array}$ & 373 parishes with Infocenters. \\
\hline
\end{tabular}




\begin{tabular}{|l|l|l|} 
Mobile classrooms (CAF, & $\begin{array}{l}\text { Trucks equipped with new } \\
\text { technologies that travel daily to } \\
\text { parishes and forums of } \\
\text { Ecuador. }\end{array}$ & $\begin{array}{l}\text { As of May 2013, 1,540 sites } \\
\text { were visited. }\end{array}$ \\
\hline $\begin{array}{l}\text { Rural training in } \\
\text { technology (known in } \\
\text { Spanish as CRT) (CAF, } \\
\text { 2013). }\end{array}$ & $\begin{array}{l}\text { Basic ICT training with mobile } \\
\text { classrooms. }\end{array}$ & $\begin{array}{l}\text { As of May 2013, 221,886 people } \\
\text { were digitally enrolled. }\end{array}$ \\
\hline
\end{tabular}

Source: own elaboration based on CAF (2013) and Mintel (2011, 2012, 2016).

The Ecuador Digital 2.0 strategy emerged as a public policy to seek urgent solutions to unresolved problems regarding the implementation of digital inclusion programs and projects in Ecuador. This strategy left outstanding debts in the educational field regarding the articulation in the delivery of technological equipment and teacher training in the proper use of ICT in the classroom.

For the 2012-2017 period, the SITEC project emerged, to comply with goal 4.4 of the National Plan For Good Living (Senplades, 2013), which promoted the provision of Internet access to $90 \%$ of public educational institutions in Ecuador, as mentioned by the Ministry of Education of Ecuador (Mineduc, 2017a):

Provide teachers of public educational institutions with computer means to access a technological platform for managing school control and a virtual learning environment known as the Online Education Community to promote innovation in the teaching-learning process and link members of the educational community. (p. 1)

For its execution, some programs and projects were determined to improve the digital skills of the country's students and teachers, increasing the use of ICT with the provision of (a) technological infrastructure to educational institutions from the public system, (b) teacher training in ICT and (c) digital educational resources for all levels of education (Sastre, 2014).

In 2012, the Mineduc launched the Mi Compu Project as a new pedagogical proposal based on the use of technology in the classroom, the school and the family nucleus, through the following aspects: (a) the delivery of a computer for each student and teacher, (b) teacher training in the use of ICT, and (c) the implementation of Internet access in educational institutions from the public system. One of the policies of this program was to allow students to take the equipment home to share it with their family, in order to improve the quality of education, achieving a change in the traditional teaching-learning paradigm. The use of the computer and the Internet, within the parameters of ethics, offers a wide variety of learning possibilities to students and, through them, to their homes and the community in general. In its pilot stage, technological devices were delivered to each of the fifth, sixth and seventh level students.

In 2015, the Ministry of Education of Ecuador promoted refresher courses in ICT, with the aim that teachers gradually incorporated technological devices into their pedagogical practice, using interactive teaching strategies that motivated students to reinforce their knowledge.

The SITEC project ended up leaving a great debt in the educational sector, since it failed to meet all the proposed goals, including the provision of technological infrastructure: technological equipment and connectivity to $90 \%$ of educational institutions from the public system in the country. Likewise, it did not meet those teacher training goals for the development of digital skills that would allow them to innovate their pedagogical practice in the classroom with the appropriate 
use of technology. Unfortunately, not all teachers in the national education system are ready to adequately implement technology in the classroom. This is due to various factors such as training programs on basic topics of technology use that did not make the leap towards techno-pedagogy, or training programs that did not cover all the teachers in the public educational system, among others.

In 2017, the Mineduc made the official launch of the Digital Educational Agenda 2017-2021, whose objective is "to strengthen and enhance the teaching-learning process in the National Educational System, through the increase of innovative practices that integrate technologies for empower learning, knowledge and participation" (Mineduc, 2017b, p. 18). This agenda is made up of five axes, which are presented in figure 1 , and which will be discussed below.

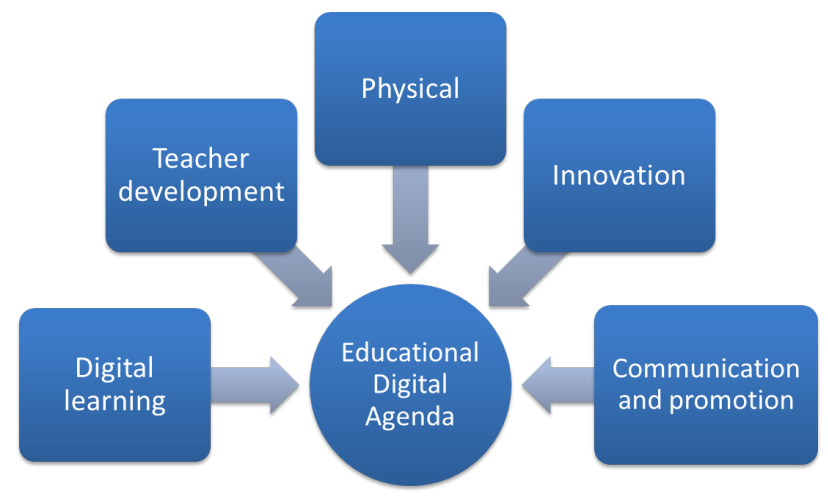

Figure 1. Goals achieved by the Ecuador Digital 2.0 Strategy, related to the education sector. Source: adapted from Mineduc (2017b).

\section{c. Physical axis}

This axis implies the phased provision of technological equipment and connectivity to public educational institutions, beginning with the provision of Internet in the administrative areas of the establishment, continuing with the connection and equipment in common educational spaces. With the delivery to teachers of a portable kit (laptop, projector and speakers), the Internet service in the classroom for the teacher is incorporated and, finally, an Internet connection in the classroom, allowing the teacher to apply active methodologies in the classroom to achieve meaningful learning (Mineduc, 2017b).

To date, it has not been possible to provide $100 \%$ of the public educational institutions with technological equipment and connectivity. In a few cases, connectivity reaches the classroom, since it remains in the administrative area of the institutions, so the proposed objective is not met. For the successful implementation of this axis, a commitment from the central government is required, since the reduction of the annual budget does not allow its fulfillment.

\section{d. Axis of digital learning}

This axis "promotes innovative pedagogical practices with a digital approach that renew teaching practices and learning processes" (Mineduc, 2017b, p. 25), for the transformation of existing educational practices. In addition, projects such as digital education, inclusive digital educational resources -interactive games in Spanish, audiobooks in Spanish and Kichwa, teacher-youtuber videos in Spanish and sign language, interactive stories in Spanish, karaoke stories in Spanish, Kichwa and sign language, and methodological guides of the reverse class teaching model-, as 
well as other audiovisual resources for broadcasting through the online educational channel EDUCA and the national educational television channel are developed.

It is important to indicate that the development of digital educational resources aligned to the National Curriculum and contextualized to the reality of Ecuador has been achieved, attending to the diversities that exist in the educational field: audio-type resources, resources in sign language, resources in Spanish and Kichwa. However, it is necessary that these efforts continue to have a constant development so that in the medium-term the entire educational community is served.

\section{e. Axis of teacher development}

This axis aims to create spaces for teacher training in information and communication technologies (ICT), learning and knowledge technologies (LKT) and technologies for empowerment and participation (TEP), for the development of innovative strategies that will allow "achieving technological inclusion competencies in the learning planning process in the classroom through the development of technical instruments, methodological guides, and spaces to share educational experiences that promote the development of social skills" (Mineduc, 2017b, p. 29 ) and circles of learning and innovation among teachers. The teacher training processes that have been developed are presented below:

- Flipped Classroom Teaching Model adapted to the Ecuadorian context.

- GeoGebra.

- Teaching of Mathematics with the use of tangible materials.

- Block programming.

- STEM strategies (Science, Technology, Engineering and Mathematics).

- Recreation and fun event for teachers.

All these initiatives that have been developed as pilots must be evaluated, corrected, and taken to massive teacher training processes to improve the 21st century skills and the quality of education in Ecuador. It is necessary that the authorities on duty dimension the importance of permanent training for teachers in the proper use of ICT, in order to improve pedagogical practices.

\section{f. Axis of innovation}

This axis is presented as a "space that encourages the emergence of new ideas that contribute to the development of digital education" (Mineduc, 2017b, p. 39), by incorporating innovative practices for the integral development of the educational community in the knowledge society. The projects developed as part of this axis are described below:

- Mobile digital classroom. It is a project that arises for the incorporation of technology in the classroom, with the aim of "promoting access to universal and quality education to contribute to equal opportunities for boys and girls, focusing on the acquisition of skills through technology and the empowerment of teachers" (Mineduc, 2017b, p. 42).

- Survey of the ICT skills of teachers in the National Educational System.

- Guidelines for the pedagogical use of the technology park of educational institutions.

Educational innovation must be seen as a gradual and permanent process, so that spaces arise where the educational community can develop to face the requirements of a changing society and in a constant process of local and global interconnection. 


\section{g. Axis of communication and promotion}

Finally, this axis ensures that the teachers of the National Educational System attached to the teaching staff of educational institutions are actively involved in educational research activities that promote innovative initiatives, aimed at the development of digital skills, both in students and teachers: "This is how teachers from Educational Institutions from their sphere of action generate spaces for innovation in the teaching-learning process" (Mineduc, 2017b, p. 37). These spaces are developed through the following projects:

- National Congress of Educational Innovation. It consists of conferences by national and international experts in educational innovation and quality of education. Experiential workshops for teachers on educational innovation and the inclusion of technology in the classroom.

- Educational Innovation Festivals. They have the objective of promoting from the educational community all those educational innovation initiatives that seek improvement in teaching-learning processes.

- Story-karaoke contest. Its purpose is to motivate teachers and authorities of the national educational system to participate in the construction of digital educational resources, using their own initiatives, abilities and skills, and the use of technological tools.

- Teacher YouTuber Contest. It aims to motivate teachers and authorities of educational institutions from any financing to share academic content as digital educational resources (tutorials) that allow improving learning in students and the general public.

- Create your Story Contest. It consists of the creation of an unpublished and original story, aimed at children and adolescents; after a style correction, the stories are illustrated and published on social networks and in the Educational Resources section of the Educar Ecuador portal.

- Hour of Code. It is an event, considered as a strategy, for the introduction to computer science through programming, with students from the age of five as the target population. The goal is for participants to explore the world of programming for one hour from simple perspectives, such as managing interactive games and sequence games, to motivate continuous learning and developing logical and computational thinking.

- Summer children's course "The world of Eugenia" I have fun with science! They are a set of workshops aimed at girls, in which scientific experiments in chemistry and physics are developed to bring girls closer to the world of science in a playful way.

- Girls in Science "The world of Eugenia". They are spaces for dialogue with the educational community to raise awareness of the importance of the incursion of girls and women in scientific careers, as well as the appropriate use of technologies in children and adolescents.

It is necessary to maintain these development spaces for the educational community that allow teachers to participate constantly in activities that promote innovative practices for the insertion of digital education in Ecuador.

In the educational atmosphere, there is a misconception about what digital education really means: it does not consist solely of providing technological infrastructure, but of training teachers and students in cutting-edge subjects that go hand in hand with the rapid growth of technology, which include important areas such as the responsible use of the Internet and social networks, as well as the development of computational thinking for the development of 21st century skills present in the knowledge society. 
The Digital Educational Agenda 2017-2021 emerged as a medium-term proposal to achieve the insertion of Digital Education in the country, for which it is required that it be elevated as a public policy, as well as the commitment of those who intervene in the fulfillment and improvement of the projects it contemplates. Likewise, to achieve the profound changes so desired in Ecuadorian education, it is necessary to extend the deadlines, as well as to achieve the political commitment and the commitment of the educational communities around this agenda, so that it becomes a proposal for implementation and permanent improvements in accordance with the demands of 21st century society. Based on all the initiatives proposed for digital inclusion in Ecuador, it is necessary to articulate the execution of these initiatives from various sectors, with the aim of generating citizens with digital skills who are able to find solutions to current problems.

All these initiatives provide great lessons that can be favorably taken advantage of by those who propose and elaborate public policies, and from this front achieve the urgent changes that Ecuador requires in the educational and technological sector.

\section{h. A pending subject: contributions to teacher training in Ecuador}

In Ecuador, a series of teacher training programs have been carried out. Despite this, Fabara (2013), in research carried out on the state of the art of training, maintains the following:

The State has made efforts and promoted policies to face the teaching problem. Some of these initiatives are relevant, but not sufficient in view of the complexity of the phenomenon. A comprehensive and systemic view and a decision to involve teachers themselves in solving their problems are outstanding above all. (p. 12)

For the development of the educational process, policies framed in the Ten-Year Education Plans were built (Mineduc, 2007, 2016b).

The Mineduc (2014) indicates that for 2014, there were "57,912 teachers taking continuing education in the areas of ICT and disciplinary updating" (p. 15). It should be noted that the training focused on computer management processes, office automation and the Internet, in dialogue with the National Plan For Good Living (2013-2017) in Policy 4.4:

Improve the quality of education at all levels and modalities for the generation of knowledge and the comprehensive training of creative, supportive, responsible, critical, participative and productive people, under the principles of equality, social equity and territoriality. (Senplades, 2013, p. 170)

But there, ICTs were treated from an artifactual approach that did not evolve towards a sociocritical approach. After nine years of the first Ten-Year Plan, even the results report focuses solely on the description of the number of hours of teacher training-cumulative results, mentioning that such number has been met by $101.21 \%$ (figure 2 ). 


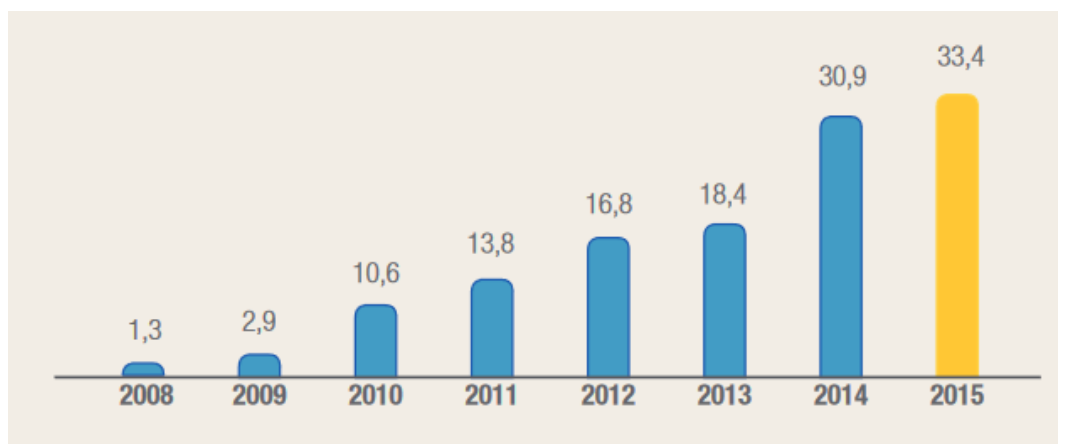

Figure 2. Number of hours of teacher training-results. Source: taken from Mineduc (2016a, p. 106).

This also comes into controversy with contributions and perspectives from Torres (2015), who states the following:

The Ten-Year Plan for Education 2006-2015 shows that in these 10 years there were disconnections with national and international policies and difficulty in making adjustments on the fly. In this decade Ecuador saw changes in many areas and, economically, the passage from an era of unprecedented ease and abundance to a crisis for which neither magnitude nor duration are yet to emerge. (para. 9)

It is at this point that there are no conclusive data that allow a deep analysis from the Mineduc, but above all, of the impact in the classroom or the experience of the teachers who have participated in different training programs and, mainly, what were the results from the pedagogical design of the contents, the platforms of use or the virtual contact between participants. Even Torres (2016) herself states that "in other words, the improvement in teacher training is measured in hours of training" (para. 16).

Thus, in this section, a literature review was carried out that allows observing different experiences developed in Ibero-America, which can serve as complements and challenges to be faced in the design of public policies for digital inclusion from teacher training. For this, the presentation is proposed from the identification of studies in the categories exposed in figure 3.

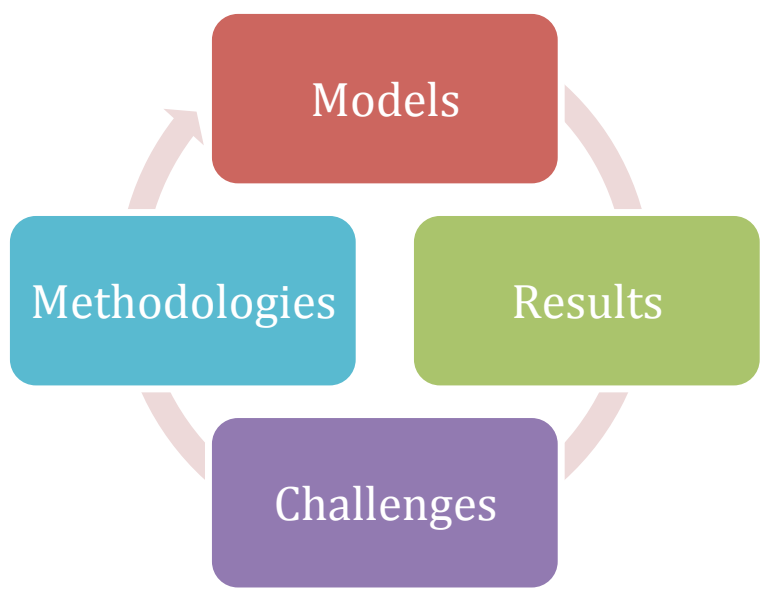

Figure 3. Categories for the presentation of studies regarding teacher training.

Source: self-made. 


\section{i. Models: beyond the technical, the importance of thinking about pedagogical designs}

Núñez, Gaviria-Serrano, Tobón, Guzmán-Calderón and Herrera (2018) propose the articulation between teacher training and technology from a transversal dialogue that takes into account teaching and training intention towards technology. For this, they establish a series of articulations between the construction of meanings that teachers make, and their practices mediated by ICT. That implies the recognition of their potential, support of the institution and reflection of its exercise teacher practice; observed from the conceptualization of teaching practice, regarding the art of education through processes and methodologies; the appropriation of a technologically mediated style, which brings the student closer and motivates learning; the teacher appropriates ICT and becomes aware of the fact that technologies are at the service of education; finally, relationships and interactions generate a constant and thoughtful communication dynamic.

In the process presented by the authors, the need for a dialogue between the practice itself, institutional support and improvements based on experience can be observed. Unfortunately, from the information provided by the Mineduc, no data have been found that allow evaluation, monitoring or accompaniment from these comprehensive axes. It should be noted that even in teacher updating programs, where it was intended to provide knowledge about the 2016 Curriculum reform, more than 180,000 teachers throughout Ecuador were trained through the use of ICT, but unfortunately there is no assessment of the impact in the practice and it only focuses on approved or non-approved participants.

With this example, the importance of what was observed in Colombia by Galvis, López and Aarón (2018) arises, who notice favorable results from the levels of interaction and knowledge of the actors, by analyzing formal educational processes at first and then linking experiences from a pedagogical design supported by the use of digital technology. Above all, the authors identified that training-related technologies allow, from the experiences of the participants, to create communities, develop flexible learning environments and strengthen advanced training programs of greater impact and lower cost. In this sense, it is not only about quantifying the hours of training and believing that this will improve the processes, as Torres (2016) sustains, but learning from the relationships that are generated and setting goals in the medium and long term.

For their part, Antúnez, Martínez and Benito (2017) indicate that the accompaniment processes are the key to teacher training. Based on a process of preparing teachers in Cuba, the authors conclude that providing the opportunity to prepare not only increases indicators in terms of training, but also "favors the teaching community and an ideal route to raise the quality of the educational teaching process and quality management" (Antúnez et al., 2017, p. 609). Therefore, face-to-face, semi-face-to-face or online training processes must establish articulated spaces in which the basis is accompaniment, monitoring and continuous dialogue. As mentioned above, there is insufficient information to identify the forms or levels of accompaniment for teachers who followed training processes accompanied by ICT. Thus, it is necessary for the Mineduc to be able to reveal figures or undertake qualitative evaluation processes from the perception of the actors, in order to see the impacts of what has been learned through processes mediated by ICT in their teaching practice.

From this, it is not enough to create programs that focus on the development of platforms or mere repositories to upload and download content. That is why Monguillot, Guitert and González (2018) propose to accompany technical experiences with a pedagogical model, in this case the Technological Pedagogical Content Knowledge (TPACK). These authors focus on design-based research (DBR) and thinking about m-learning experiences from its structure. From this they demonstrate:

The importance of integrating different methodological and evaluation strategies based on active methodologies and emerging pedagogies in order to enhance 21 st century skills such 
as problem solving through negotiation, critical thinking and effective communication through teamwork. (p. 58)

To finish, they present the TPACKPEC model under a transdisciplinary approach, motivating the design of courses to articulate them from technological knowledge, personal knowledge, curricular knowledge and pedagogical knowledge, to integrate ICT in teaching-learning processes, taking mainly into account the emotions of the participants.

This model dialogues with the proposals of Hepp, Prats and Holgado (2015), who indicate that the TPACK model has been one of the processes with the greatest penetration in relation to technology and education, but that there are barriers and challenges that go from instructional, up to teachers and disciplinarians (table 3 ).

\begin{tabular}{|l|l|}
\hline \multicolumn{2}{|c|}{ Farrier or challenge } \\
\hline The institution & $\begin{array}{l}\text { Institutional practices, available ICT infrastructure and flexibility to make } \\
\text { curricular changes. }\end{array}$ \\
\hline The students & Digital culture and personal ICT infrastructure. \\
\hline Second order & $\begin{array}{l}\text { Self-efficacy, attitude towards ICT, personal ICT infrastructure and } \\
\text { perceived incentives. }\end{array}$ \\
\hline The teacher & $\begin{array}{l}\text { Knowledge of the contribution of ICT to enrich environments and solve } \\
\text { learning or teaching knots in the specific subjects of each teacher, and the } \\
\text { type of ICT to be used (hardware and software) and how to use it inside } \\
\text { and outside the classroom. }\end{array}$ \\
\hline The disciplines & \\
\hline
\end{tabular}

Table 3. Barriers or challenges to the TPACK model

Source: adapted from Hepp, Prats and Holgado (2015, p. 36).

Another of the models that became relevant towards technology-mediated training has to do with Massive and Open Online Courses (MOOCs). From this, Garrido et al. (2016) present a series of guidelines to take into account from the design of these platforms, always in dialogue with public policy and government entities as actors that motivate and strengthen initiatives (figure 4). 
Governments must integrate MOOCs into existing training programs and coordinate programs among agencies and other entities.

Governmental agencies must partner with educational institutions, libraries and

social organizations and implement MOOC awareness strategies that start in the

primary and secondary education.

MOOC developers must increase their presence in social networks to create

awareness among young people about these learning platforms and their potential

use to advance on employability goals.

MOOC developers must dedicate efforts to partner with intermediary institution

such as schools, public libraries, and other social organizations working with

young people.

Figure 4. Guidelines for the design of platforms for teacher training.

Source: adapted from Garrido et al. (2016).

As can be seen, there are still outstanding aspects for the development of teacher training processes. Although it is true that endowment and connections were necessary in Ecuador, after ten years -2007 to $2017-$ it is expected that other aspects will be deepened to allow the understanding of ICT-mediated education as a comprehensive process that requires a dialogue between public policy, institutions and actors. In addition, government entities are invited to develop communication processes in relation to the accountability of the impact that the implemented programs have had as ways of analyzing them and presenting proposals for improvements.

\section{j. Results: the key is the motivation, experience of the participants and support}

Starting from the identification of the needs from a comprehensive articulation, experiences are presented in which relevant results have been achieved around ICT-mediated teacher training and how this can have an impact on the educational reality. Thus, Aguilar (2015) presents some challenges to teacher training from research carried out at the medium level in Mexico. Based on the analysis of the results obtained from the Comprehensive Reform of Higher Middle Education (RIEMS by its initials in Spanish), the author maintains that progress in this area has been important, but that it requires greater integration from the actors, as well as landing the needs of the contexts and, above all, making the content more flexible. In this sense, the need arises for the Mineduc to reflect on its practices and results of experiences from programs and projects in teacher professional development, both face-to-face and mediated by technologies, to improve its public policy processes.

In this regard, there are experiences that report favorable results when creating pedagogical designs from ICTs. For example, for the Venezuelan context, González (2016) affirms that taking advantage of technologies in teacher training is clearly reflected in the future practices of teachers and, therefore, in their students. Similarly, from Spain Viñals and Cuenca (2016) explain that the 
key to training processes mediated by technologies largely depends on the linking of teaching methodologies and the attitude and motivation of the actors.

Regarding the perspectives of students who are in initial teacher training, from the results of the study by Esteve, Gisbert and Lázaro (2016) in Spain, it can be seen that young people between 20 and 24 years old consider that they use digital skills. Despite this, when consulting methodological strategies for teaching through ICT in the classroom, the percentages tend to drop. In this sense, a relevant challenge for the development of programs or projects in Ecuador has to do with not only training in technical spaces or content managers, but rather reflecting on the previous step that represents the planning and motivation of the participants.

It should be noted, from contributions by Gaible and Burns (2005), that for a model of teacher professional development to be effective it must start from a process that considers the experience of the participants (figure 5 ).

Approach the teachers' and students' needs through methods that are appropriate for the conditions in schools.

Being in the long-term, continuous, sequenced and cumulative, providing teachers with opportunities to obtain new knowledge and skills, reflect on changes in their teaching practice and increase their skills on time.

Focus on the learning results from students in a way in which teachers can use their new knowledge and skills.

Instruction centered on the student from the model, so that teachers experiment and reflect on the learning activities they lead.

Use formative and summative assessment to improve the program.

Figure 5. Guidelines for pedagogical design for online teacher training.

Source: adapted from Gaible and Burns (2005, p. 17).

To finish, it is relevant to mention the work carried out by Patiño, Palomino and Rivero (2018), who present a regional panorama of studies on teacher training. This team applied a survey in order to generate a contribution in the educational field mediated by ICT from the experiences of online learning teachers, through the following aspects: "(a) motivational, (b) management of technological and virtual resources, (c) learning experience, (d) use of the virtual platform, (e) metacognition, and (f) learning achievements "(Patiño et al., 2018, p. 52). From the analysis of the situation in Peru, the authors mention that teachers have basic skills for managing platforms, mainly Moodle. In addition, they use different devices to connect to training programs. Participation in peer learning communities and the accompaniment of videoconferences was also key to the realization of the modules. Therefore, the use of platforms, the usability of devices and the accompaniment contribute to improve teacher performance. But, above all, it is important to use open platforms that allow its development and connection with different modules or applications. 


\section{k. Challenges: planned and contextualized ICT-mediated teacher training}

Based on the above, some challenges have been established from different research that could be linked and serve as a guide for compliance with public policies in the Ecuadorian context. This is how Martínez, Yániz and Villardón (2018) argue that teacher training has the challenge of approaching the knowledge society, but that they requires self-evaluation and reflection processes, in relation to the fact that "efforts to advance in the creation of tools and processes that facilitate adaptations of teaching actions to the educational needs of students must be intense and constant" (p. 25). In other words, in the Ecuadorian case, it is not enough to offer face-to-face or virtual courses or training, but rather a long-term public policy process that exceeds the quantified assessment and that promotes qualitative evaluations in relation to these experiences must be built.

Continuing with this proposal, Rodríguez and López (2017), based on a study carried out in Spain and Argentina, state that teachers need to "make variations on performances where the teacher interacts, but further accentuating their role as mediator, where 'letting do' is more possible "( $p$. 14). Against this, it is key for the design of programs in Ecuador to understand that the training processes mediated by ICT must value the essence that is generated from practice, that is, open, ubiquitous and flexible learning, where the teacher is a guide and propose challenges that go beyond formal curricular compliance. In this way, it is possible to get closer to the daily life of the actors and, from this, take advantage of digital platforms that complement their training.

For their part, Burns and Lawrie (2015) raise a breaking point towards successful experiences that goes beyond perceiving the good. For this, seven recommendations are made that become challenges for future programs and projects related to ICT-mediated teacher training (Figure 6).

Recommendation 1: Focus on the teachers on fragile contexts, as

professionals, students and individuals.

Recommendation 2: Develop, apply, measure and institutionalize

standards for the teachers' professional development.

Recommendation 3: Create opportunities for professional development

that promotes teaching collaboration.

Recommendation 4: Provide ongoing support for teachers.

Recommendation 5: Invest on high quality teacher's trainers.

Recommendation 6: Build educational leadership at all levels in the

educational system.

Recommendation 7: Use ICTs to provide access to content, professional

development and professional learning communities

Figure 6. Challenges for programs and projects that take into account teacher training.

Source: adapted from Burns and Lawrie (2015, p. 5). 
The Regional Office of Education for Latin America and the Caribbean [Orealc / Unesco], in a study carried out on teacher training experiences in the Region (Cuenca, 2015), managed to determine that one of the keys that has improved the quality of education is to generate strategies, stimuli and incentives that allow high-achieving students to choose the teaching profession, generating value before them and before society. For this reason, Cuenca (2015) clarifies that "motivation as a triggering process for a change 'from the teachers', to later impact on social perceptions on themselves" ( $p .35$ ). That is to say, the challenge facing this process in the case of future studies is to link, not only subjects related to content, but campaigns that strengthen the teaching identity.

For their part, Darling, Hyler and Gardner (2017) provide, after an analysis of different proposals, a framework of initiatives that must be considered from public policy when undertaking spaces for teacher training (Figure 7).

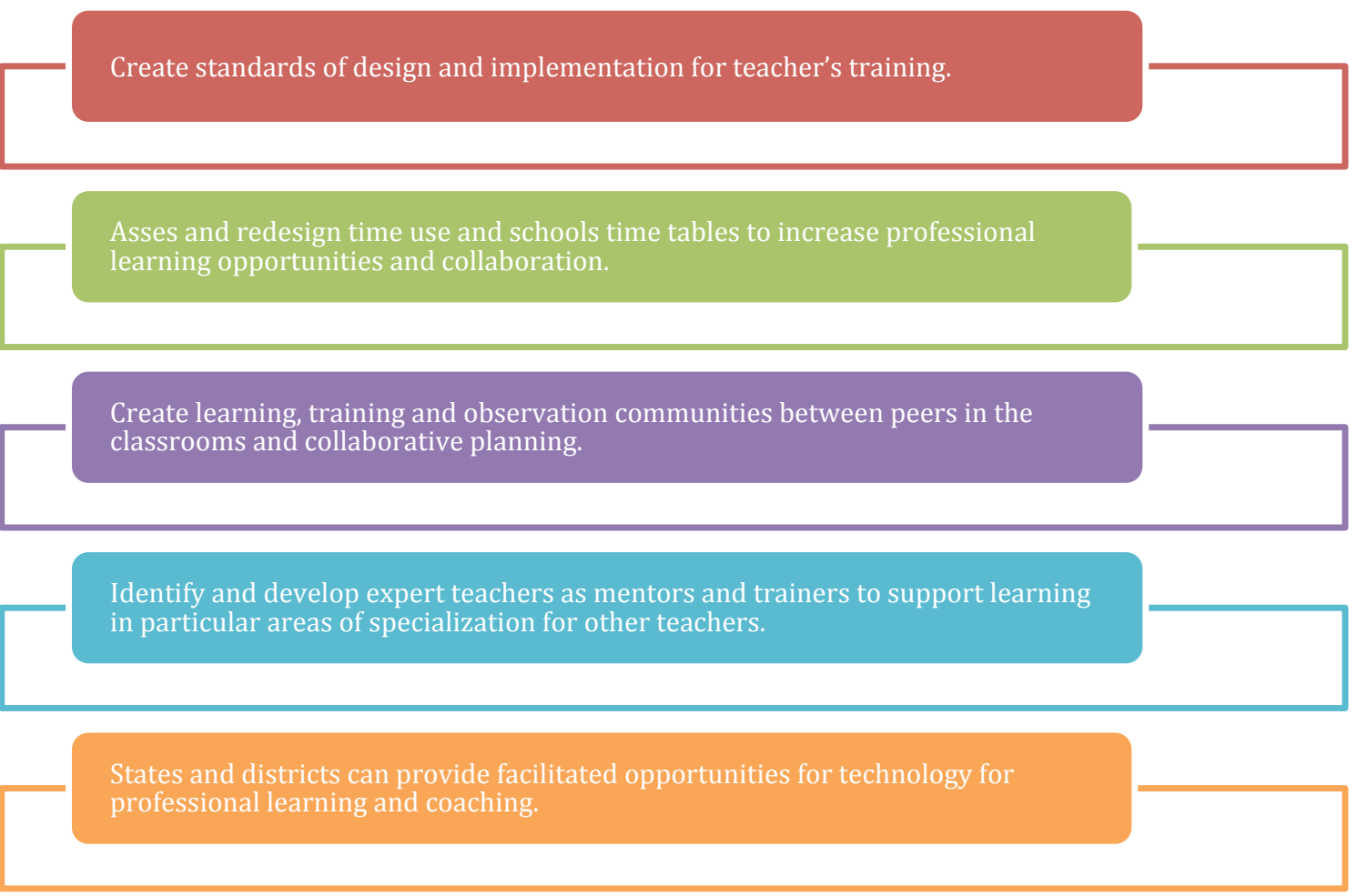

Figure 7. Initiatives for the design of public policy when undertaking spaces for teacher training.

Source: adapted from Darling et al. (2017).

Another challenge that the teaching profession is currently facing, from the contributions of Elacqua et al. (2018), is its delegitimization and the loss of prestige due to different factors. For this reason, it is necessary to "restore prestige to the teaching profession" (p. 199). This factor is key, since any face-to-face or virtual training initiative, program or plan developed by the government, will not cause an impact if the people who are the axis of change do not feel this way. Of course, there are different types of motivations. Although it is true that budget constraints can be an impediment to economic motivation, it is possible to structure other types of incentives that tend to create awareness and commitment of the actors. 


\section{By way of conclusions: outstanding debts for digital inclusion in Ecuador}

The various initiatives in policies, strategies, programs and projects for digital inclusion in Ecuador in recent years have pointed towards the achievement of similar goals in the education sector, whose names have been changing, in some cases taking some of the previous proposals and, in others, incorporating new ideas.

Some of these proposals were very ambitious and little planned in the determined times for their implementation. In this way, there is a great debt with the education sector, since to date, it has not been possible to meet all the proposed goals, including the provision of technological infrastructure to all public educational institutions in the country; that is, it has not yet been possible to deliver $100 \%$ of technological and connectivity equipment.

Likewise, it has not been possible to meet those goals of teacher training for the development of digital skills that allow them to innovate their pedagogical practice in the classroom with the appropriate use of technology. Unfortunately, teachers in the national education system are not yet ready to adequately implement technology in the classroom. This is due to various factors such as the following: training programs in basic topics of technology use that do not make the leap towards a socio-critical approach; training programs that do not cover all the teachers in the public system, and a poor qualitative approach to the impact of these initiatives.

In the educational atmosphere there is a misleading idea about what digital education means. This does not consist solely of the provision of technological infrastructure, but of training educational actors in content that allows their humanistic and critical development from technology, not as an end, but as a means. It is not enough to teach how to use a computer or its programs; it is not enough to create digital platforms that only serve as repositories to download information and upload tasks; above all, it is not enough to continue pretending that public policy is a matter for each minister, secretary or authority in charge at a given time, because this does not allow proper monitoring and evaluation of these initiatives, which can be very beneficial. On the contrary, it is required to research the impacts from micro-social environments, to articulate the initiatives in long-term programs that go beyond the current governments and that, particularly, respond to each educational reality, without pretensions to become recipes.

From these proposed initiatives for digital inclusion in Ecuador, it is necessary to articulate, from various sectors, its contextualized execution, in order not only to quantify the participants or approved of a course, or how many computers exist in educational institutions, but to generate citizens with digital skills that are capable of questioning possible solutions to the problems that the society of the 21st century requires, but also accompany these initiatives with programs to strengthen the teaching identity, as well as their motivation and their transcendental role in each community.

Finally, all these initiatives provide great lessons that can be used favorably for those who propose and elaborate public policies and, from this front, achieve the urgent changes that Ecuador requires regarding the development of comprehensive strategies that link education, actors and technology. 


\section{References}

Adell, J. (1997). Tendencias en educación en la sociedad de las tecnologías de la información. Edutec, Revista electrónica de tecnología educativa, 7, 1-21. doi: 10.21556/edutec. 1997.7.570

Aguilar, J. (2015). Desafíos de la investigación en formación docente del nivel medio superior en México. Perfiles educativos, 37, 89-107. Recuperado de https://www.iisue.unam.mx/perfiles/perfiles_articulo.php?clave=2015-e-89-107

Antúnez, J., Martínez, Y., \& Benito, V. (2017). Perfeccionamiento docente de profesores egresados de la formación tecnológica en salud. MediSan, 21(5), 608-610. Recuperado de http://scielo.sld.cu/pdf/san/v21n5/san15215.pdf

Augé, M. (1993). Los no lugares: espacios del anonimato. España: Gedisa.

Balardini, S. (2002). Jóvenes, tecnología, participación y consumo. Argentina: Clacso.

Burns, M. \& Lawrie, J. (Eds.). (2015). Where It's Needed Most: Quality Professional Development for All Teachers. New York: Inter-Agency Network for Education in Emergencies. Recuperado de http://s3.amazonaws.com/ineeassets/resources/Where_Its_Needed_Most__Teacher_Professional_Development_2015_LowRes.pdf

Consejo Nacional de Telecomunicaciones (Conatel). (2005). Plan de acción 2005-2010. Recuperado de https://www.gobiernoelectronico.gob.ec/wp-content/uploads/2018/09/Plan-deAcci\%C3\%B3n-2005-2010-de-la-Agenda-Nacional-de-Conectividad.pdf

Consejo Nacional de Telecomunicaciones (Conatel). (2006). Libro Blanco. Estrategia para el desarrollo de la sociedad de la información en Ecuador-EDSI. Quito: Conatel.

Corporación Andina de Fomento (CAF). (2013). Sector TIC: Ecuador. Recuperado de http://scioteca.caf.com/handle/123456789/580

Cuenca, R. (2015). Las carreras docentes en América Latina: la acción meritocrática para el desarrollo profesional. Unesco. Recuperado de https://unesdoc.unesco.org/ark:/48223/pf0000244074

Darling, L., Hyler, M., \& Gardner, M. (2017). Effective teacher professional development. Recuperado de https://learningpolicyinstitute.org/sites/default/files/productfiles/Effective_Teacher_Professional_Development_REPORT.pdf

Elacqua, G., Hincapie, D., Vegas, E., Alfonso, M., Montalva, V., \& Paredes, D. (2018). Profesión: Profesor en América Latina: ¿Por qué se perdió el prestigio docente y cómo recuperarlo? Inter-American Development Bank. Recuperado de https://publications.iadb.org/publications/spanish/document/Profesi\%C3\%B3n-Profesoren-Am\%C3\%A9rica-Latina-Por-qu\%C3\%A9-se-perdi\%C3\%B3-el-prestigio-docente-yc\%C3\%B3mo-recuperarlo.pdf

Esteve, F., Gisbert, M., \& Lázaro, J. (2016). La competencia digital de los futuros docentes: ¿Cómo se ven los actuales estudiantes de educación? Perspectiva Educacional, Formación de Profesores, 55(2), 38-54. Recuperado de https://www.redalyc.org/pdf/3333/333346580004.pdf

Fabara, E. (2013). Estado del arte de la formación docente en el Ecuador. Cuadernos del Contrato Social por la Educación, 8, 1-102. Recuperado de http://contratosocialecuador.org/images/publicaciones/cuadermos/8.pdf 
Facultad Latinoamericana de Ciencias Sociales Sede Ecuador (Flacso). (2005). La Agenda de Conectividad del Ecuador. Recuperado de https://biblio.flacsoandes.edu.ec/catalog/resGet.php?resId $=25940$

Gaible, E., \& Burns, M. (2005). Using Technology to Train Teachers: Appropriate Uses of ICT for Teacher Professional Development in Developing Countries. Recuperado de http://unpan1.un.org/intradoc/groups/public/documents/unpan/unpan037314.pdf

Galvis, Á., López, Y., \& Aarón, M. (2018). Aprendiendo de una transformación de prácticas pedagógicas en cursos de maestría en la modalidad híbrida de aprendizaje. Revista de Educación a Distancia, 58(2), 1-35. Recuperado de https://www.um.es/ead/red/58/galvis_et_al.pdf

Garrido, M., Koepke, L., Anderson, S., Felipe Mena, A., Macapagal, M., \& Dalvit, L. (2016). The advancing moocs for development initiative: An examination of mooc usage for professional workforce development outcomes in Colombia, the Philippines, \& South Africa. Recuperado de: https://www.irex.org/sites/default/files/node/resource/examination-mooc-usageprofessional-workforce-development-outcomes.pdf

González, M. (2016). Formación docente en competencias TIC para la mediación de aprendizajes en el Proyecto Canaima Educativo. Telos: Revista de Estudios Interdisciplinarios en Ciencias Sociales, 18(3), 492-507. Recuperado de https://www.redalyc.org/pdf/993/99346931009.pdf

Hepp, K., P., Prats, M. \& Holgado, J. (2015). Formación de educadores: la tecnología al servicio del desarrollo de un perfil profesional innovador y reflexivo. RUSC. Universities and Knowledge Society Journal, 12(2). 30-43. doi: 10.7238/rusc.v12i2.2458

Jurado, R. (2005). Diagnóstico de las políticas de TIC en el Ecuador. Recuperado de http://www.flacso.org.ec/docs/diagnostico_tic.pdf

López, F. (2002). El análisis de contenido como método de investigación. XXI, Revista de Educación, 4, 167-179. Recuperado de https://dialnet.unirioja.es/servlet/articulo?codigo=309707

Martínez, M., Yániz, C., \& Villardón, L. (2018). Autoevaluación y reflexión docente para la mejora de la competencia profesional del profesorado en la sociedad del conocimiento. Revista de Educación a Distancia, 56, 1-30. Recuperado de https://www.um.es/ead/red/56/martinez_et_al.pdf

Ministerio de Educación de Ecuador (Mineduc). (2007). Plan decenal de educación 2006-2015. Recuperado

de http://www.siteal.iiep.unesco.org/sites/default/files/sit_accion_files/ec_9029.pdf

Ministerio de Educación de Ecuador (Mineduc). (2014). Rendición de Cuentas educativas Ecuador 2014. Recuperado de https://educacion.gob.ec/wpcontent/uploads/downloads/2015/06/Rendicion-de-Cuentas-2014.pdf

Ministerio de Educación de Ecuador (Mineduc). (2016a). Evaluación plan decenal de educación 2006-2015. Recuperado de http://dano.com.ec/rosamariatorres/plan-decenalevaluaci\%C3\%B3n.pdf

Ministerio de Educación de Ecuador (Mineduc). (2016b). Propuesta de la comunidad educativa para el Nuevo Plan Decenal de Educación 2016-2025. Recuperado de https://educacion.gob.ec/wp-content/uploads/downloads/2016/03/PLAN-DECENALPROPUESTA.pdf

Ministerio de Educación de Ecuador (Mineduc). (2017a). Ficha Informativa de Proyecto 2017 SITECSistema Integral de Tecnologías para la Escuela y la Comunidad. Recuperado de 
https://educacion.gob.ec/wp-content/uploads/downloads/2017/06/Sistema-Integral-de-

Tecnologias-para-la-Escuela-y-la-Comunidad-SITEC.pdf

Ministerio de Educación de Ecuador (Mineduc). (2017b). Agenda Educativa Digital 2017-2021. Recuperado de https://educacion.gob.ec/wp-content/uploads/downloads/2017/11/AgendaEducativa-Digital.pdf

Ministerio de Telecomunicaciones y de la Sociedad de la Información (Mintel). (2011). Presentación de la Estrategia Ecuador Digital 2.0. Recuperado de http://instrumentosplanificacion.senplades.gob.ec/documents/20182/21649/EstrategiaEcua dorDigital2011.pdf/232001e7-1b27-4165-94f2-efd23ccf5211

Ministerio de Telecomunicaciones y de la Sociedad de la Información (Mintel). (2012). Conectividad Social en Ecuador. Quito: Mintel. Recuperado de https://www.cepal.org/sites/default/files/presentations/juan_pablo_torres_mintel_p3.pdf

Ministerio de Telecomunicaciones y de la Sociedad de la Información (Mintel). (2016). Plan Nacional de Telecomunicaciones Tecnologías de Información del Ecuador 2016-2021. Recuperado de https://www.telecomunicaciones.gob.ec/wp-content/uploads/2016/08/Plande-Telecomunicaciones-y-TI..pdf

Monguillot, M., Guitert, M., \& González, C. (2018). TPACKPEC: Diseño de situaciones de aprendizaje mediadas por TIC en educación física. Movimiento, 24(3), 749-764. doi: $10.22456 / 1982-8918.76681$

Núñez, C., Gaviria-Serrano, J., Tobón, S., Guzmán-Calderón, C., \& Herrera, S. (2019). La práctica docente mediada por TIC: una construcción de significados. Espacios, 40(5), 1-15. Recuperado de https://www.revistaespacios.com/a19v40n05/a19v40n05p04.pdf

Patiño, A., Palomino, L., \& Rivero, C. (2017). Docentes y sus aprendizajes en modalidad virtual: aportes para la reflexión y construcción de políticas docentes. Lima: Unesco. Recuperado de http://repositorio.minedu.gob.pe/handle/MINEDU/5709

Ramos, C., Apolo, D., \& Jadán, J. (2018). Jóvenes y política: una revisión de estudios desde latinoamerica. Observatorio (OBS*), 12(1), 169-182. Recuperado de http://obs.obercom.pt/index.php/obs/article/view/1162

Rigal, L. (2004). El sentido de educar: crítica a los procesos de transformación educativa. Buenos Aires.: Miño y Dávila.

Rodríguez, A., \& López, R. (2017). Estrategias de enseñanza en los entornos mediados: resultados de la experiencia de la performance virtual educativa. Revista de Educación a Distancia, 55, 1-14. Recuperado de http://revistas.um.es/red/article/view/315371

Sastre, A. (2014). Programas de Alfabetización Digital en América Latina. Montevideo: Centro de Estudios de telecomunicaciones de América Latina.

Secretaría Nacional de Planificación y Desarrollo (Senplades). (2007). Plan Nacional de Desarrollo 2007-2010, Planificación para la Revolución ciudadana. Recuperado de https://www.planificacion.gob.ec/wp-content/uploads/downloads/2013/09/Plan-NacionalDesarrollo-2007-2010.pdf

Secretaría Nacional de Planificación y Desarrollo (Senplades). (2009). Plan Nacional de Desarrollo 2009-2013. Recuperado de https://www.planificacion.gob.ec/wpcontent/uploads/downloads/2012/07/Plan_Nacional_para_el_Buen_Vivir.pdf

Secretaría Nacional de Planificación y Desarrollo (Senplades). (2013). Plan Nacional de Desarrollo 2013-2017, Para el Buen Vivir. Recuperado de 
http://ftp.eeq.com.ec/upload/informacionPublica/2013/PLAN-NACIONAL-PARA-EL-BUENVIVIR-2013-2017.pdf

Secretaría Nacional de Planificación y Desarrollo (Senplades). (2017). Plan Nacional de Desarrollo 2017-2021, Toda una Vida. Recuperado de https://www.planificacion.gob.ec/wpcontent/uploads/downloads/2017/10/PNBV-26-OCT-FINAL_OK.compressed1.pdf

Torres, R. (2015). Ecuador ¿Otro plan decenal de educación? Recuperado de https://otraeducacion.blogspot.com/2016/01/ecuador-otro-plan-decenal-de-educacion.html

Torres, R. (2016). El Ministro mintió: Plan Decenal de Educación 2006-2015 (Ecuador). Recuperado de https://otra-educacion.blogspot.com/2016/01/ecuador-otro-plan-decenal-deeducacion.html

Valles, M. (1999). Técnicas cualitativas de investigación social. Reflexión metodológica y práctica profesional. Madrid: Editorial Síntesis Sociología.

Viñals, A. \& Cuenca J. (2016). El rol del docente en la era digital. Revista Interuniversitaria de Formación del Profesorado, 30(2), 103-114. Recuperado de https://www.redalyc.org/pdf/274/27447325008.pdf 